\title{
Insecticide application rate in coffee crop: qualitative and quantitative aspects and efficacy of leaf miner control
}

\author{
Thiago Lima Melo1 (iD), Carlos Gilberto Raetano2 (iD), Adriana Dias Cardoso ${ }^{(1 D}$, Aldenise Alves Moreira ${ }^{1}$ (D), \\ Suzany Aguiar Leite ${ }^{1}$ (D) Maria Aparecida Castellani ${ }^{1}$ (D)
}

${ }^{1}$ Universidade Estadual do Sudoeste da Bahia/UESB, Vitória da Conquista, BA, Brasil

${ }^{2}$ Universidade Estadual Paulista Júlio de Mesquita Filho/UNESP, Departamento de Proteção Vegetal , Botucatu, SP, Brasil

Contact authors: thiagolimelo@bol.com.br, carlos.raetano@unesp.br, adriuesb@yahoo.com.br, aldenise.moreira@gmail.com, suzanyleite@yahoo.com.br, castellani@uesb.edu.br Received in February 18, 2020 and approved in May 15, 2020

\begin{abstract}
Leaf miner is a key coffee crop pest in Central and South America countries, especially in Brazil, where the insect causes considerable production losses. In the management of this insect pest, insecticide applications at reduced rates are fundamental for improve the operational capacity of the sprayer and the rational use of water. Thus, the aim of this study was to select a application rate that ensures effectiveness of cyantraniliprole, cartape hydrochloride and beta-cypermethrin insecticides in the leaf miner control, good spraying quality with varying application rates and low impact on natural parasitism. The qualitative and quantitative aspects of spraying with the Brilliant Blue marker were evaluated at the following rates: $28.1,60.5,80.2$ and $180.0 \mathrm{~L}$ ha ${ }^{-1}$ and the efficacy of cyantraniliprole, cartape hydrochloride and beta-cypermethrin insecticides, with doses of the commercial formulations. Pest infestation and parasitism were determined before and after applications. Application rate interferes with qualitative aspects and spray deposition levels. Considering the quality-quantitative aspects and Agronomic Efficacy, rates between 80.2 and $180.0 \mathrm{~L} \mathrm{ha}^{-1}$ are the most suitable for the control of this insect. Cyantraniliprole insecticide is effective in controlling L. coffeella up to 45 DAA at rate of $180.0 \mathrm{~L} \mathrm{ha}^{-1}$. The impact of cyantraniliprole, cartape hydrochloride and beta-cypermethrin insecticides on $L$. coffeella natural parasitism varies with application rates and time after application.
\end{abstract}

Key words: Brilliant blue marker; beta-cypermethrin; cartape hydrochloride; cyantraniliprole; Leucoptera coffeella.

\section{INTRODUCTION}

Leaf miner (Leucoptera coffeella Guérin-Mèneville \& Perrottet, 1842) (Lepidoptera: Lyonetiidae) causes indirect production losses by causing leaf injury, reducing photosynthesis capacity due to coffee leaf area reduction. Intense attack causes plant defoliation and, consequently, reduction of coffee production and longevity (Reis; Souza, 2002). Populations of this insect are affected by the complex of natural enemies, temperature, humidity, spacing, plant nutrition, biennial crop production, mulching and chemical applications (Parra; Reis, 2013).

In the state of Bahia, two regions stand out in the production of Coffea arabica L., and leaf miner is the factor of greatest obstacle and concern to economic productions. The western region has a technified production chain and optimal conditions for the development of the pest, such as high temperatures and low relative humidity practically all year round. This leads to increased levels of pest infestation, significant production losses and intensive use of insecticides (Melo et al., 2007). In this region, chemical control is practically the only strategy used for pest suppression with at least, for most farms, two systemic insecticide applications and 15 annual sprayings (Castellani et al., 2016). In the highland region, predominant crops are rainfed and infestation levels are relatively lower in relation to the western region, due to the weather conditions with lower temperatures and higher relative humidity, unfavorable to the insect. However, in recent years, there have been cases of unsuccessful use of insecticides for pest control, requiring an increase in the number of sprays and, consequently, greater use of water and risk of environmental contamination.

Effective, economical and sustainable application of insecticides is necessary for any crop. The use of application technology with reduced application rates aims to improve sustainable pest control, as well as its effectiveness, which is effectively related to the type of nozzle and operating characteristics used during spraying, allowing good coverage uniformity and minimal loss by drift (Silva; Cunha; Nomelini, 2014; Morais et al., 2016).

The use of spray equipment associated with different application rates (Miranda et al., 2012) have been of great relevance for coffee growers in controlling L. coffeella. Recent studies have indicated that it is possible to significantly reduce insecticide application rates to control leaf miner with conventional equipment, while maintaining good quality of applications and product efficacy (Miranda et al., 2013; Silva et al., 2014; Decaro Junior et al., 2015; Gitirana-Neto et al., 2016; Melo et al., 2019).

The variation in the application rate from 43 to $309 \mathrm{~L} \mathrm{ha}^{-1}$ contributed significantly to the management of Neotropical leaf miner in the coffee tree in São Desidério, BA, Brazil (Melo et al., 2019). This work proposes to reduce on average $44 \%$ the application rates ( 28 to $\left.180 \mathrm{~L} \mathrm{ha}^{-1}\right)$ and the use different 
insecticides for the management of this insect pest in coffee tree in Barra do Choça, BA, Brazil.

In view of the above, the aim of this study was to select application rates that guarantees effectiveness of cyantraniliprole, cartape hydrochloride and beta-cypermethrin insecticides in the control of leaf miner, ensuring good spraying quality with reduced application rates and low impact on natural parasitism.

\section{MATERIAL AND METHODS}

Studies were conducted from November 2016 to January 2017 on coffee crop, 'Catucaí' cultivar ( 8 years old), with spacing of $3.7 \times 0.5 \mathrm{~m}$, comprising an experimental area of approximately 1.5 ha, located in the Vanderlúcia Farm (-14 '56'59'S and -40³4'40”'W), municipality of Barra do Choça, BA. Cultivation was carried out in a rainfed system, composed of plants with approximate height of two meters. The average annual temperature of the region is $19.9^{\circ} \mathrm{C}, 900$ $\mathrm{mm}$ rainfall and $900 \mathrm{~m}$ a.s.l.

\subsection{Q ualitative and quantitative aspects of spraying}

Due $t$ o the homogeneity of conditions in the experimental area, the experimental design was completely rand o mized with 4 treatments (application rates) and six replicates, totaling 24 plots. Plots consisted of three planting lines with $15 \mathrm{~m}$ in length. Only the central line was sprayed, which is considered useful for evaluations and the other lines were border plants.

Treatments consisted of spraying the solution with the $0.15 \%$ Brilliant Blue marker (FD\&C No. 1) at $0.15 \%\left(\mathrm{~m} \mathrm{v}^{-1}\right)$, selected for studies due to its good stability in sunlight (Alves; Cunha; Palladini, 2014), in the application rates (Table 1). Application was performed with Massey Ferguson tractor model $255 \mathrm{~F}, 4 \times 2 \mathrm{TDA}$, with $37.2 \mathrm{~kW}$ of engine power at operacional speed. The sprayer used was the air-assisted transport jet, model Arbus 400 jet, with capacity of 400 liters, 16 nozzles, equipped with axial fan of $850 \mathrm{~mm}$ in diameter and $11 \mathrm{~m}^{3} \mathrm{~s}^{-1}$ air flow, piston pump and control independent from the liquid distribution in the respective spray lines. Only hydraulic system on the boom side of the sprayer with 8 empty conic nozzles was used. The working speed was $6 \mathrm{~km} \mathrm{~h}^{-1}$; rotation of the power take-off transmission of 540 RPM; and working pressure of $550 \mathrm{kPa}$ (5.5 bar) for all treatments. The application rates with the respective spray nozzles and pressure were measured with nominal flow rate established by the manufacturer (Table 1).

To evaluation of spray coverage and other qualitative char acteristics of spraying, water-sensitive papers (76 x 26 $\mathrm{mm}$ ) were distributed in two plants of each plot, in the upper third (place of highest incidence of pest attack), positioned betw een the third and fifth pair of leaves of plagiotropic branches and both sides of plants in front of the spraying. Each paper was stapled to the adaxial leaf surface, totaling 2 per plant, 4 per plot. After spraying, water-sensitive papers were removed from plants with the aid of surgical gloves, placed in $\mathrm{kraft}$ paper bags, packed and transported in polystyrene box, sent to the Laboratory of Entomology, Southwest Bahia Stat e University, Campus of Vitória da Conquista - BA. Images of cards were digitized on a flatbed scanner with 600 dpi optical resolution and analyses were performed using the Gota s 1.0 software (Embrapa, 2014). The qualitative spray parameters evaluated were: number of droplets; droplet density (No $\mathrm{cm}^{-2}$ ); volumetric median diameter (DMV); numerical median diameter (NDM); uniformity coefficient (r); coverage percentage; and application rate $\left(\mathrm{L} \mathrm{ha}^{-1}\right)$.

Table 1: Application rates with empty conic nozzles and flow rate $\left(\mathrm{L} \mathrm{min}^{-1}\right)$ in spraying using the Brilliant Blue marker dye. Barra do Choça, BA, 2017.

\begin{tabular}{cccc}
\hline $\begin{array}{c}\text { Application } \\
\text { rate }\left(\mathrm{L} \mathrm{ha} \mathrm{h}^{-1}\right)\end{array}$ & Spray nozzle & $\begin{array}{c}\text { Flow rate } \\
\left(\mathrm{L} \mathrm{min}^{-1}\right)\end{array}$ & Droplet Size \\
\hline 28.1 & $\mathrm{X} 0.5^{*}$ & 0.05 & $\mathrm{MF}^{1}$ \\
60.5 & $\mathrm{X} 1.0^{*}$ & 0.13 & $\mathrm{MF}$ \\
80.2 & $\mathrm{X} \mathrm{2.0^{* }}$ & 0.17 & $\mathrm{MF}$ \\
180.0 & $\mathrm{HB} 01^{* *}$ & 0.36 & $\mathrm{MF}$ \\
\hline
\end{tabular}

${ }^{*}$ X Series of Magnojet; ${ }^{* *} \mathrm{HB}$ Micron; ${ }^{1}$ MF = very fine (Magnojet, 2015).

Quantitative analyses were performed after the application of solution containing the marker dye and removal of water-sensitive papers. A leaf placed next to each card was collected, placed in a plastic bag (polypropylene), packed and transported in polystyrene box and sent to the laboratory. Leaves were kept refrigerated $\left(8 \pm 3{ }^{\circ} \mathrm{C}\right)$ until the time of analysis for marker quantification. The abaxial and adaxial surfaces of leaves were washed inside a Becker using $20 \mathrm{~mL}$ of distilled water and by removing by shaking any marker attached to plastic bags used as a means of transporting the leaves. The resulting solution was collected and deposited in plastic bottles, kept in the absence of light and under refrigeration $\left(8 \pm 3^{\circ} \mathrm{C}\right)$. Samples were submitted to a Bioespectro spectrophotometer (SP-22 Spectrophotometer) for absorbance reading at wavelength of $630 \mathrm{~nm}$. Subsequently, leaves were individually submitted to the bench leaf area meter (model LI-3.100, LICOR, USA) to determine the corresponding leaf area.

To calculate deposits, initially, Brilliant Blue marker (ppm) concentrations at different dilutions were determined. From these data, the standard curve was constructed between the absorbance readings measured by the spectrophotometer and concentrations. The amount of marker in the spray was proportional to the application rate. A single equation was used for all treatments (Figure 1) and deposit values were calculated as a function of the initial volume and leaf area of each sample. 


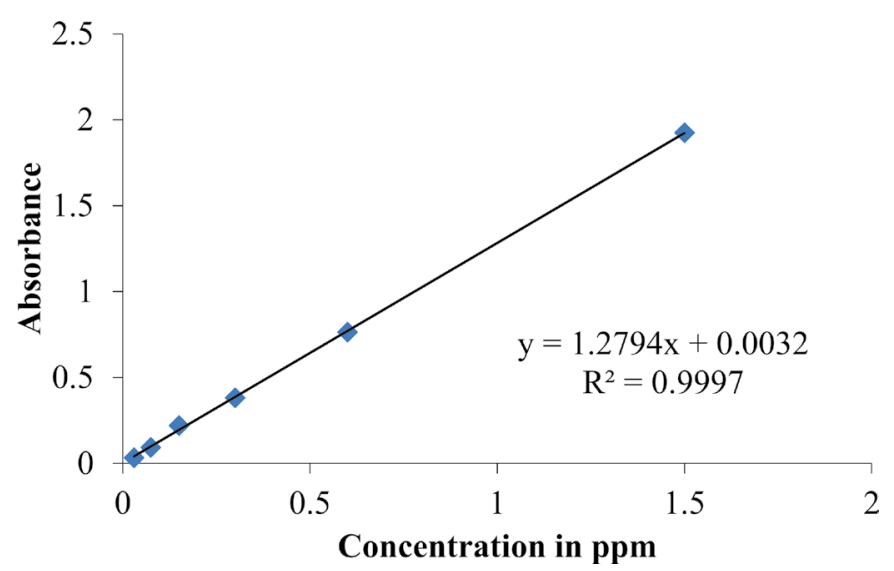

Figure 1: Absorbance reading curve to infer Brilliant Blue marker concentration in the spray solution.

\subsection{Effectiveness of insecticides on leaf miner control and impact on natural parasitism}

The experimental design was completely randomized, and treatments were distributed in the $4 \times 3+1$ factorial scheme, four application rates $\left(28.1,60.5,80.2\right.$ and $\left.180.0 \mathrm{~L} \mathrm{ha}^{-1}\right)$ combined with three insecticides and one control treatment (without insecticide application), in three replications, totaling 39 plots. Plots consisted of three $30 \mathrm{~m}$ long crop lines totaling 60 plants; the central line was considered useful for evaluations, and the others as border. Treatments consisted of spraying commercial insecticide formulations of the following chemical groups: diamide-cyantraniliprole (100 g a.i. $\mathrm{L}^{-1}$, suspension concentrated in oil, DuPont, Paulínia, SP, Brazil), thiocarbamate - cartape hydrochloride (500 g a.i. kg-1, soluble powder, Sumitomo, Sao Paulo, SP, Brazil); and pyrethroid - beta-cypermethrin (100 g a.i. $\mathrm{L}^{-1}$, emulsifiable concentrate, Arysta, Sao Paulo, SP, Brazil) at reduced application rates obtained with different spray nozzles and recommended dose in commercial formulations for this insect pest, $0.7 \mathrm{~L} \mathrm{ha}^{-1}, 1.0 \mathrm{~kg} \mathrm{ha}^{-1} \mathrm{e} 0.15 \mathrm{~L} \mathrm{ha}^{-1}$, respectively, as registered with the Brazilian Ministry of Agriculture, Cattle and Supplying (Mapa, 2017).

Individual spray solutions were prepared for each treatment, with same dose for each volume applied. The spray hydrogen potential $(\mathrm{pH})$ was measured with a digital $\mathrm{pH}$ meter, and there was no need for correction $(\mathrm{pH} \mathrm{5)}$, considering that acid $\mathrm{pH}$ reduces the chance of molecule loss by hydrolysis.

Spraying was performed on December 10, 2016, from 8:40 am to 11:20 am. The tractor and sprayer used, as well as the general procedures, were the same as described for studies with the Blue marker. Meteorological data on temperature, relative humidity and wind speed before and during spraying were recorded by a thermohygrometer (Model HT-3003) and anemometer (Model AM-4201), both 38 Lutron brand, and are expressed in Table 2 .
Table 2: Meteorological conditions at the time of application of cyantraniliprole, cartape hydrochloride and beta-cypermethrin commercial insecticides. Barra do Choça, BA, 2017.

\begin{tabular}{ccccc}
\hline $\begin{array}{c}\text { Volume L } \\
\text { ha }^{-1}\end{array}$ & $\begin{array}{c}\text { Application } \\
\text { time }\end{array}$ & $\begin{array}{c}\text { Temperature } \\
\left({ }^{\circ} \mathrm{C}\right)\end{array}$ & RH $(\%)$ & $\begin{array}{c}\text { Wind } \\
\left(\mathrm{km} \mathrm{h}^{-1}\right)\end{array}$ \\
\hline $28.1\left(^{*}\right)$ & $08: 40 \mathrm{am}$ & 30.6 & 60.0 & $0.1-1.8$ \\
$60.5\left(^{*}\right)$ & $08: 55 \mathrm{am}$ & 29.2 & 60.0 & $1.9-2.0$ \\
$80.2\left(^{*}\right)$ & $09: 07 \mathrm{am}$ & 29.9 & 56.8 & $0.2-1.6$ \\
$180.0\left(^{*}\right)$ & $09: 20 \mathrm{am}$ & 30.0 & 56.9 & $1.1-2.2$ \\
$28.1\left(^{* *}\right)$ & $09: 37 \mathrm{am}$ & 28.4 & 56.0 & $1.5-2.8$ \\
$60.5(* *)$ & $09: 49 \mathrm{am}$ & 28.8 & 60.0 & $1.0-1.8$ \\
$80.2(* *)$ & $10: 02 \mathrm{am}$ & 28.5 & 55.0 & $0.2-2.7$ \\
$180.0(* *)$ & $10: 16 \mathrm{am}$ & 30.1 & 54.0 & $2.3-3.2$ \\
$28.1(* * *)$ & $10: 34 \mathrm{am}$ & 31.0 & 52.0 & $3.5-3.8$ \\
$60.5(* * *)$ & $10: 48 \mathrm{am}$ & 30.5 & 51.0 & $1.9-3.8$ \\
$80.2(* * *)$ & $11: 03 \mathrm{am}$ & 30.3 & 53.0 & $0.5-2.7$ \\
$180.0(* * *)$ & $11: 20 \mathrm{am}$ & 30.6 & 51.0 & $1.6-4.2$ \\
\hline
\end{tabular}

* cyantraniliprole; ${ }^{* *}$ cartape hydrochloride ${ }^{* * *}$ beta-cypermethrin.

Infestation and natural parasitism evaluations were carried out in four samples: one before application (previous) and at 15, 30 and 45 days after application (DAA) of insecticides. Sampling was performed in the upper third of four plants randomly taken per plot, collecting the fourth leaf pair on all four sides of the plant, totaling 8 leaves per plant, 32 leaves per plot and 1248 leaves in each evaluation. Collected leaves were placed in properly identified Kraft paper bags, packed and transported in polystyrene box to the Laboratory of Entomology at UESB, where they were kept at room temperature during the evaluation period (three days).

With the aid of a stereoscopic microscope, infested leaves were counted, those with at least one live larval lesion and those containing mines with parasitoid pupae and / or parasitoid exit holes, according to methodology described by Melo et al. (2007). Infestation and natural parasitism indexes were calculated using the following formulas: Infestation Index $(\%)=$ (number of leaves with live caterpillars in mines/total number of leaves) x 100 and Parasitism Index $(\%)=($ number of parasitized mines/total number of mines) x 100 .

The Henderson and Tilton (1955) formula was adopted to calculate the Agronomic Efficacy (E\%) of treatments:

$E(\%)=100 x\left[1-\left(\frac{N I V T A A}{N I V T D A}\right) X\left(\frac{N I V T D A}{N I V T A A}\right)\right]$

Where: $\mathrm{E}(\%)=$ Agronomic Efficacy; NIV = number of living insects; TAA $=$ number of living insects on control before application, TDA = number of living insects on treatment after application. 
Parasitism reduction was calculated using Abbott's formula (1925) and the classification of insecticides for toxicity was performed according to the International Organization for Biological and Integrated Control of Noxious Animals and Plants (IOBC) (Boller et al., 2005), due to the reduction of the population of natural enemies: a) Harmless or slightly toxic (N): 0 to $50 \%$; b) Moderately toxic (M): 51 to $75 \%$; c) Toxic (T): above $75 \%$.

The data were subjected to homogeneity and normality variances tests, and transformed answer the premises of the analysis of variance. The means of the treatments (insecticides) were compared by the Tukey test, the spray volumes were studied by regression analysis and the comparison between the control and the treatments was made using the Dunnett test, at $5 \%$ probability. All analyzes were performed using the SAEG program (System for Statistical and Genetic Analysis) Version 9.1 (Ribeiro Júnior, 2001).

\section{RESULTS AND DISCUSSION}

\subsection{Qualitative and qualitative evaluation of spraying}

Significant effect of application rate on number and density of droplets, DMV, DMN, spray coverage (\%) and recovered volume $\left(\mathrm{L} \mathrm{ha}^{-1}\right)$ was found in the upper third of coffee plants (Table 3). Only the uniformity coefficient of the droplet spectrum, the effect of the application rate were not significant.

The effects of application rates on the number and density of droplets can be explained by quadratic models. For number of droplets, there is an increase up to the rate of $130.04 \mathrm{~L} \mathrm{ha}^{-1}$, reaching, on average, 1,740.58 droplets per water-sensitive card, an increase of $281.74 \%$ over the lowest rate (617.79 droplets). From the maximum point of the curve $\left(130.04 \mathrm{~L} \mathrm{ha}^{-1}\right)$, there was a decrease in the number of droplets up to the maximum rate (180.0 $\mathrm{L} \mathrm{ha}^{-1}$ ) (Figure 2A). The density of droplets increases to the maximum point of the curve $\left(129.90 \mathrm{~L} \mathrm{ha}^{-1}\right)$, with density of 9.99 and increase of $297 \%$ compared to the lowest density of 3.58 droplets $\mathrm{cm}^{-2}$, which was obtained in the lowest application rate $\left(28.1 \mathrm{~L} \mathrm{ha}^{-1}\right)$. From the rate at the maximum point, density decreases up to the maximum rate $\left(180.0 \mathrm{~L} \mathrm{ha}^{-1}\right)$ (Figure $2 \mathrm{~B}$ ). Overall, droplet densities obtained at all application rates were very low compared to those recommended for insecticide applications (Ozeki et al., 2010).

The results show that the increase in the application rate increases the density of droplets up to $129.9 \mathrm{~L} \mathrm{ha}^{-1}$. From that volume the density and the number of drops decrease (Figures 2A and 2B). This is probably due to the coalescence of very fine droplets up to the point of maximum leaf saturation, reflecting in larger size spots on the water-sensitive paper. This artificial target is a selective surface for droplets smaller than 50 micrometers in diameter, as they would not have enough energy to deposit by sedimentation. However droplets with diameters between 60 to 145 micrometers, classified as very fine (Asabe, 2009) can deposit on this surface but when in high density it overestimates the size of the droplets. This fact can be seen in Figures 2C and 2D.

The effect of the application rate on DMV follows a quadratic model, with increasing values up to $134.98 \mathrm{~L} \mathrm{ha}^{-1}$, where it reaches $916.64 \mu \mathrm{m}$ and decreases from there on (Figure 2C), values much higher than those recommended by the manufacturer of nozzles in the respective operating conditions (Table 1). The effect of application rates on DMN was linear, indicating that this characteristic increases with increasing volume (Figure 2D). In both cases the coalescence of the drops increases the size of the spots on the watersensitive paper and overestimates the size of the drops with values from $717.77 \mu \mathrm{m}$ to $1,155.24 \mu \mathrm{m}$ at rates of 28.1 and $180.0 \mathrm{~L} \mathrm{ha}^{-1}$, respectively. In general, DMV values obtained in the present study characterize very thick droplets according to the BCPC classification (Souza; Palladini, 2007), which was not expected, at least for the lowest application rates (28.1, 60.5, and 80.2 $\left.\mathrm{L} \mathrm{ha}^{-1}\right)$, as a function of nozzles used. According to Magnojet's catalog, X-series nozzles (X0.5; X1; and X2) under the operating conditions used in the experiment should ge nerate very thin droplets (Magnojet, 2015). The droplet spectra obtained at the four application rates suggest the occurrence of runoff (beyond the maximum leaf saturation capacity), since, in the three largest volumes, values were above or near $800 \mu \mathrm{m}\left(28.1 \mathrm{~L} \mathrm{ha}^{-1}-536.3 \mu \mathrm{m} ; 60.5 \mathrm{~L} \mathrm{ha}^{-1}-\right.$ 930.01 $\left.\mu \mathrm{m} ; 80.2 \mathrm{~L} \mathrm{ha}^{-1}-783.6 \mu \mathrm{m} ; 180.0 \mathrm{~L} \mathrm{ha}^{-1}-829.3 \mu \mathrm{m}\right)$ (Zhu et al., 1994; Wolf, 2000; Cunha et al., 2003). Differences in plant architecture and insertion of leaves in branches can influence spray coverage and the droplets coalescence.

Table 3: Summary of the variance analysis for characteristics number and density of droplets, volumetric median diameter (DMV), numerical median diameter (DMN), coverage and volume recovered after spraying on coffee plants. Barra do Choça, BA, 2017.

\begin{tabular}{|c|c|c|c|c|c|c|c|}
\hline \multirow{2}{*}{ FV } & \multirow{2}{*}{ G L } & \multicolumn{6}{|c|}{ Mean Squares } \\
\hline & & Number of Droplets & Density & DMV & $\mathrm{DMN}$ & Coverage & Recovered Volume \\
\hline Rates (T) & 3 & $1068300.00 *$ & $34.74 *$ & $104719.80 *$ & $48351.29 *$ & $110.15^{*}$ & $8349.91 *$ \\
\hline Residue & 20 & 47202.95 & 1.54 & 20209.90 & 15067.61 & 7.36 & 559.31 \\
\hline $\mathrm{CV}(\%)$ & & 18.43 & 18.27 & 18.85 & 20.23 & 30.56 & 32.54 \\
\hline
\end{tabular}

*Significant at $5 \%$ probability according to $\mathrm{F}$ test. 

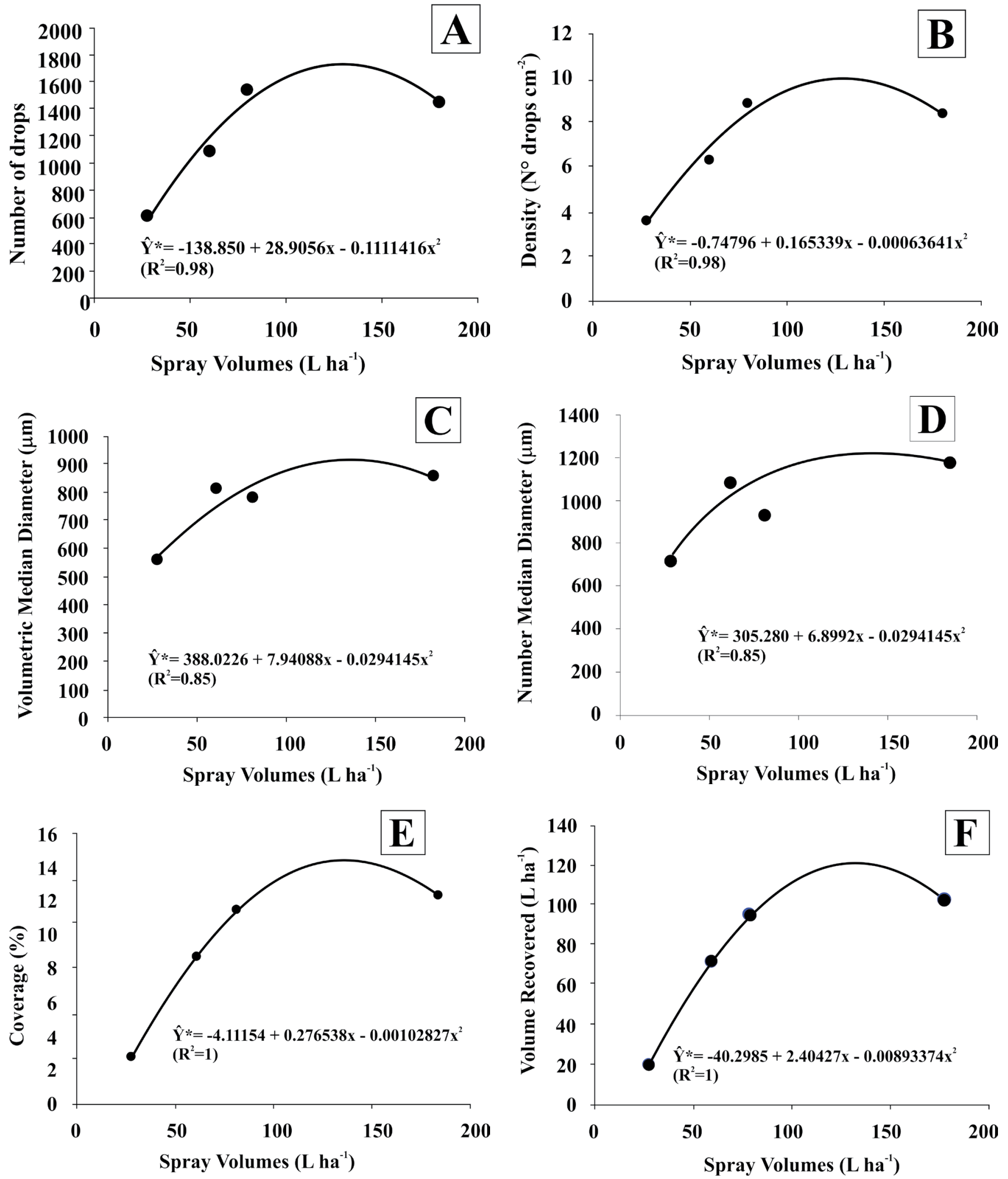

Figure 2: Estimation of the number $(A)$ and density of droplets $(B)$, volumetric median diameter $(C)$, numerical median diameter $(D)$, coverage estimate $(E)$ and recovered spray volume $(F)$ in water-sensitive cards after spraying of the Brilliant Blue marker on coffee, as a function of the application rates. Barra do Choça, BA, 2017.

Significant at $5 \%$ probability by regression analysis of variance. 
For the spraying coverage results (\%), quadratic effect was observed, with an increase rate up to $134.47 \mathrm{~L} \mathrm{ha}^{-1}$, reaching $14.48 \%$ of covered area, an increase of $502.78 \%$ in relation to the lowest rate, which resulted in $2.88 \%$ coverage. From this point, a small decrease in coverage percentage was observed, reaching $12.34 \%$ at rate of $180.0 \mathrm{~L} \mathrm{ha}^{-1}$ (Figure 2E). In none of the rates under study, the spraying coverage was satisfactory, being less than $20 \%$ and also smaller in relation to some results obtained for coffee, as the works of Scudeler et al. (2004) and Ferreira et al. (2013), who worked with application rates higher than those used in the present work. On the other hand, the results were very close to those obtained in 'Catuaí' crop by Santinato et al. (2017). It is also worth mentioning that the architecture of the 'Catucaí' cultivar is different from that used by Scudeler et al. (2004) and Ferreira et al. (2013), in this case, 'Catuaí' cultivar (IAC-99), respectively 4.5 years old and $2.0 \mathrm{~m}$ in height and 12 years old and $3.50 \mathrm{~m}$ in height.

In the recovered volume, the effect is explained by the quadratic model, indicating that the recovered volume grows to the applied volume of $134.56 \mathrm{~L} \mathrm{ha}^{-1}$, reaching 121.46 , from which it decreases slightly, with better correlation for volumes of 60.5. $\mathrm{L} \mathrm{ha}^{-1}$ and $80.2 \mathrm{~L} \mathrm{ha}^{-1}$, which had their total volumes recovered. The volume of $180.0 \mathrm{~L} \mathrm{ha}^{-1}$ resulted in the worst recovery, around $57 \%$ of the applied volume. In general, the three smallest application rates $\left(28.1,60.5\right.$, and $\left.80.2 \mathrm{~L} \mathrm{ha}^{-1}\right)$ determined good recovery level, as can be seen in the Figure $2 \mathrm{~F}$.

The good levels of recovery of the applied volume with rates below $80 \mathrm{~L} \mathrm{ha}^{-1}$ and very fine droplets show little influence of the meteorological conditions (Table 2).

The characteristics of the coffee leaf surface and architecture of the coffee plant can determine greater drop retention with reduced losses. In a way, it was found that the loss of the marker solution was relatively low, which was not expected due to the high DMV values, recorded by the analysis of images of water-sensitive papers that would indicate the runoff of droplets with size greater than $800 \mu \mathrm{m}$ (Decaro Júnior et al., 2015). Despite the coalescence of the droplets with larger spots on the water-sensitive paper, the interaction between application rate, spray solution and plant characteristics that control spray loss on coffee plant.

\subsection{Quantitative assessment of spray applications}

The application rate on marker deposit values on coffee leaves had significant effect (Table 4). For spray deposition levels, the model was positive line ar, which best explained the variations, with deposit increments due to increased application rates (Figure 3). The se results were expected, since the spraying of larger spray volumes frequently results in larger deposits, as alre ady verified in coffee leaves (Rodrigues et al., 2012; Melo et al., 2019) and fruits (Miranda et al., 2012).
Table 4: Summary of variance analysis to spray deposit of the Brilliant Blue marker on coffee leaves, as a function of application rate. Barra do Choça, BA, 2017.

\begin{tabular}{ccc}
\hline FV & GL & Mean Squares \\
\cline { 3 - 3 } & & Deposit \\
\hline Rates $(\mathrm{T})$ & 3 & $0.00725807^{*}$ \\
Residues & 15 & 0.00363712 \\
CV (\%) & & 48.87 \\
\hline
\end{tabular}

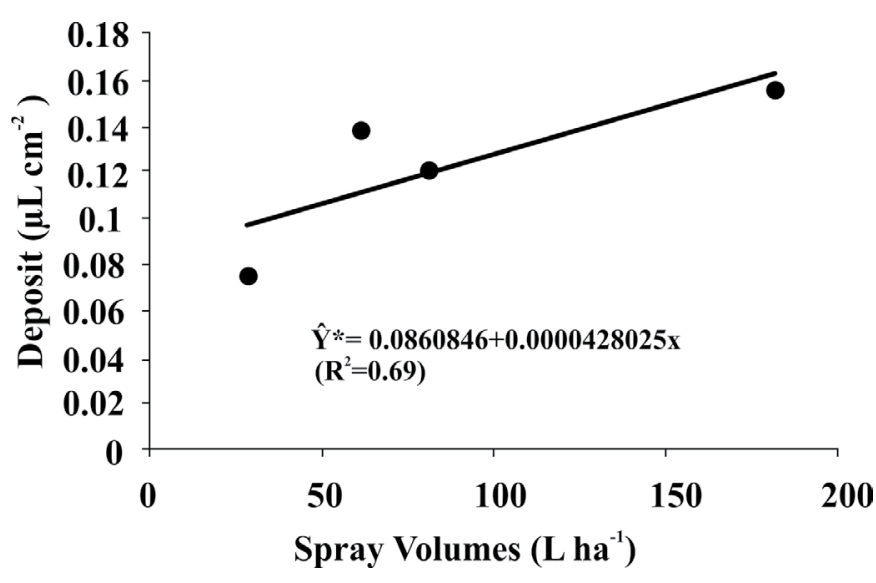

Figure 3: Estimation of Brilliant Blue marker deposit on coffee leaves as a function of application rates. Barra do Choça, BA, 2017.

\subsection{Effectiveness of insecticides to control leaf miner}

Significant effect of insecticide factor was verified on the leaf miner infestation at 30 and 45 days after application (DAA). The application rate factor and the interaction between rate $\mathrm{x}$ insecticide did not show any significant interaction during all evaluation times. In addition, effect of the interaction of factors application rate and insecticide in relation to the control in leaf miner infestation at 30 and 45 days after insecticide application was also verified (Table 5).

Considering the significant effects of the interaction between application rates and insecticide with control, it was observed that leaf miner infestation before insecticide spraying (previous) was uniform in the experimental area, without significant differences among plots to be sprayed (Table 6).

At 15 DAA, all treatments were equal to control, with no significant differences among treatments, although agronomic efficiencies were above $80 \%$ for most treatments, except for cyantraniliprole and $60.5 \mathrm{~L} \mathrm{ha}^{-1}$ cartape hydrochloride, cyantraniliprole and beta cypermethrin at rates of 80.2 and 180.0 $\mathrm{L} \mathrm{ha}^{-1}$, respectively (Table 6). 
Table 5: Summary of variance analysis to Leucoptera coffeella infestations at 30 and 45 days after application (DAA) of cyantraniliprole, cartape hydrochloride and beta-cypermethrin insecticides. Barra do Choça, BA, 2017.

\begin{tabular}{|c|c|c|c|}
\hline \multirow{2}{*}{$\mathrm{FV}$} & \multirow{2}{*}{ GL } & \multicolumn{2}{|c|}{ Mean Squares } \\
\hline & & $30 \mathrm{DAA}^{1}$ & $45 \mathrm{DAA}^{1}$ \\
\hline Rate (T) & 3 & 1.16 & 17.63 \\
\hline Insecticide (I) & 2 & $4.48^{*}$ & $983.89^{*}$ \\
\hline $\mathrm{T} \times \mathrm{I}$ & 6 & 0.31 & 53.98 \\
\hline$(\mathrm{T}, \mathrm{I}) \times$ Control & 1 & $22.99^{*}$ & $2150.13 *$ \\
\hline Residue & 26 & 0.80 & 32.55 \\
\hline $\mathrm{CV}(\%)$ & & 26.29 & 38.22 \\
\hline
\end{tabular}

${ }^{*}$ Significant at $5 \%$ probability, according to $\mathrm{F}$ test; ${ }^{1}$ Days after application.

Table 6: Leucoptera coffeella infestation (INF) in coffee trees, in the previous evaluation and at 15,30 and 45 days after application (DAA) of insecticides and their agronomic efficacy (AE\%), as a function of application rates. Barra do Choça, BA, 2017.

\begin{tabular}{|c|c|c|c|c|c|c|c|c|}
\hline \multirow{2}{*}{\multicolumn{2}{|c|}{ Treatment }} & \multicolumn{7}{|c|}{ Evaluations } \\
\hline & & \multirow{2}{*}{$\begin{array}{l}\text { Previous } \\
\text { INF (\%) }\end{array}$} & \multicolumn{2}{|c|}{15 DAA } & \multicolumn{2}{|c|}{30 DAA } & \multicolumn{2}{|c|}{45 DAA } \\
\hline Rate $\left(\mathrm{L} \mathrm{ha}^{-1}\right)$ & Insecticide & & INF (\%) & $\mathrm{AE}(\%)$ & INF (\%) & $\mathrm{AE}(\%)$ & INF (\%) & $\mathrm{AE}(\%)$ \\
\hline \multirow{3}{*}{28.1} & Cyantraniliprole & $34.37 \mathrm{a}^{*}$ & 3.13 & 91.18 & $3.17 \mathrm{~b} * *(10.42)$ & 71.43 & $1.92 b(4.17)$ & 89.74 \\
\hline & Cartape hydrochloride & $37.50 \mathrm{a}$ & 6.25 & 83.82 & $3.71 b(13.54)$ & 65.96 & $3.56 \mathrm{~b}(12.50)$ & 71.80 \\
\hline & Beta-cypermethrin & $41.67 \mathrm{a}$ & 6.21 & 85.54 & $3.71 b(13.54)$ & 69.36 & $4.72 \mathrm{a}(21.88)$ & 55.58 \\
\hline \multirow{3}{*}{60.5} & Cyantraniliprole & $34.37 \mathrm{a}$ & 8.33 & 76.47 & $2.64 \mathrm{~b}(8.33)$ & 77.14 & $1.74 b(3.13)$ & 92.31 \\
\hline & Cartape hydrochloride & $28.12 \mathrm{a}$ & 11.46 & 60.46 & $3.11 b(9.38)$ & 68.57 & $3.30 \mathrm{~b}(10.42)$ & 68.66 \\
\hline & Beta-cypermethrin & $38.54 \mathrm{a}$ & 7.29 & 81.64 & $3.60 \mathrm{~b}(13.54)$ & 66.87 & $5.18 \mathrm{a}(27.08)$ & 40.54 \\
\hline \multirow{3}{*}{80.2} & Cyantraniliprole & $32.78 \mathrm{a}$ & 7.29 & 78.41 & $1.74 b(3.13)$ & 91.01 & $1.74 b(3.13)$ & 91.93 \\
\hline & Cartape hydrochloride & $48.96 \mathrm{a}$ & 4.17 & 91.74 & $2.96 \mathrm{~b}(8.33)$ & 83.95 & $3.99 b(16.67)$ & 71.20 \\
\hline & Beta-cypermethrin & $43.75 \mathrm{a}$ & 7.29 & 83.82 & $3.43 b(11.46)$ & 75.31 & $4.73 \mathrm{a}(21.88)$ & 57.69 \\
\hline \multirow{3}{*}{180.0} & Cyantraniliprole & $37.50 \mathrm{a}$ & 7.29 & 91.07 & $2.60 \mathrm{~b}(6.25)$ & 84.29 & $1.34 b(2.08)$ & 95.30 \\
\hline & Cartape hydrochloride & $47.79 \mathrm{a}$ & 5.21 & 93.36 & $3.25 \mathrm{~b}(10.42)$ & 79.45 & $4.12 b(16.67)$ & 70.49 \\
\hline & Beta-cypermethrin & $33.33 \mathrm{a}$ & 7.29 & 78.77 & 4.26a (18.75) & 46.96 & $3.72 b(13.54)$ & 65.63 \\
\hline Control & & $34.37 \mathrm{a}$ & 35.42 & & $6.06 \mathrm{a}(36.46)$ & & $6.40 \mathrm{a}(40.63)$ & \\
\hline
\end{tabular}

Agronomic Efficacy (Henderson; Tilton, 1955); ${ }^{*}$ Means followed by the same lower case letter in the column do not differ from each other by the Dunnett's test at $5 \%$ significance; ${ }^{* *}$ Statistical analysis performed on data transformed into $\sqrt{ }(X+0.5)$; Original averages in parentheses.

At the second evaluation (30 DAA), only treatment with beta-cypermethrin at rate of $180.0 \mathrm{~L} \mathrm{ha}^{-1}$ behaved similarly to control; the others determined significantly smaller infestations. However, only cyantraniliprole at rates of 80.2 and 180.0 $\mathrm{L} \mathrm{ha}^{-1}$ and cartape hydrochloride at 80.2 $\mathrm{L} \mathrm{ha}^{-1}$ resulted in efficiencies above $80 \%$ (Table 6).

At 45 DAA, it is still possible to verify the effect of insecticides on the leaf miner population, since the infestation levels were relatively lower than those observed in the previous evaluation. In this last evaluation, only cyantraniliprole was efficient in pest control in the four studied rates (Table 6).

Analysis of the effect of insecticides on the pest population at 30 and 45 DAA shows significant differences between insecticides, regardless of application rate. Cyantraniliprole differed significantly from beta- cypermethrin at 30 DAA and from beta-cypermethrin and cartape hydrochloride at 45 days, significantly reducing pest population. Thus, beta-cypermethrin showed the worst performance in both evaluations and cartape hydrochloride, intermediate performance (Table 6).

Thus, it is possible to reduce the application rate and maintain agronomic efficacy since in the present work the same product at rates of 80.2 and $180.0 \mathrm{~L} \mathrm{ha}^{-1}$ enabled good control efficacy, $91.01 \%$ and $84.22 \%$, respectively.

This reduction in the application rate; however, requires improvement of the application technology. The use of smaller spray volume increases the autonomy and operating capacity of sprayers, also reducing the risks of environmental contamination, as it reduces runoff and, in some cases, evaporation and drift. With the increase of operational 
capacity, the machine starts to spray large areas in good weather conditions (Christofoletti, 1999).

Considering only the effects of insecticides on the infestation rates, significant differences were found between treatments. At 30 DAA, cyantraniliprole differed from beta-cypermethrin, with lower infestation, and both were equal to cartape chloridarate. At 45 DAA, infestations were significantly different in treatments with the three insecticides, with cyantraniliprole showing the best performance, followed by cartape hydrochloride and beta-cypermethrin, which had the worst performance in pest control (Table 7). The better performance and crop protection in the control of leaf miner obtained by cyantraniliprole may be related to its systemic mode of action. Cartape hydrochloride has contact and ingestion action; however, the translaminar effect is also attributed to the product. Beta-cypermethrin, on the other hand, is a pyrethroid with contact and ingestion action only, which probably limits its efficacy, since leaf miner caterpillars are protected by the leaf epidermis, which hinders the action of the product.

\subsection{Impact on natural parasitism}

Overall, parasitism rates were low and did not exceed $20 \%$ (Table 8), as found in studies conducted in coffee plantations in county of Luís Eduardo Magalhães (Melo et al., 2007) and Vitória da Conquista (Souza et al., 2014).
Table 7: Leucoptera coffeella infestation in coffee plants at 30 and 45 days after insecticide application (DAA). Barra do Choça, BA, 2017.

\begin{tabular}{ccc}
\hline \multirow{2}{*}{ Insecticide } & \multicolumn{2}{c}{ Evaluations } \\
\cline { 2 - 3 } & $30 \mathrm{DAA}$ & $45 \mathrm{DAA}$ \\
\hline Cyantraniliprole & $2.64 \mathrm{~b}(6.47)$ & $3.39 \mathrm{c}$ \\
Cartape hydrochloride & $3.26 \mathrm{ab}(10.13)$ & $14.07 \mathrm{~b}$ \\
Beta-cypermethrin & $3.75 \mathrm{a}(14.33)$ & $21.10 \mathrm{a}$ \\
\hline
\end{tabular}

Means followed by the same lowercase letter in the column do not differ from each other by the Tukey test at $5 \%$ significance; Statistical analysis performed on data transformed into $\sqrt{ }(X+0.5)$; Original averages in parentheses.

Insecticides were innocuous at 15 days and showed some selectivity as a function of application rates. Parasitism reduction (PR) rates for cyantraniliprole insecticide allowed it to be classified as harmless at 15 DAA at all application rates, toxic at $30 \mathrm{DAA}\left(28.1 \mathrm{~L} \mathrm{ha}^{-1}\right)$, moderately toxic (180.0 $\left.\mathrm{L} \mathrm{ha}^{-1}\right)$ and toxic (28.1 and 80.2 $\mathrm{L} \mathrm{ha}^{-1}$ ) at 45 DAA. Cartape hydrochloride was classified as harmless at 15 and 30 DAA, harmless (180.0 $\left.\mathrm{L} \mathrm{ha}^{-1}\right)$, moderately toxic $\left(60.5 \mathrm{~L} \mathrm{ha}^{-1}\right)$ and toxic (28.1 and $\left.80.2 \mathrm{~L} \mathrm{ha}^{-1}\right)$. Beta-cypermethrin was classified as harmless at 15 DAA in all volumes, toxic at 30 DAA only at volume of $80.2 \mathrm{~L} \mathrm{ha}^{-1}$ and moderately toxic at $28.1,80.2$ and 180.0 $\mathrm{L} \mathrm{ha}^{-1}$ (Table 8).

Table 8: Parasitism Rate (IP\%) and respective Parasitism Reduction (RP\%) in the upper third of coffee trees according to the evaluation period, before (previous) and at 15, 30 and 45 days after insecticide application - DAA. Barra do Choça, BA, 2017.

\begin{tabular}{|c|c|c|c|c|c|c|c|c|}
\hline \multirow{2}{*}{ Insecticide } & \multirow{2}{*}{$\begin{array}{l}\text { Volume } \\
\left(\mathrm{L} \mathrm{ha}^{-1}\right)\end{array}$} & \multicolumn{7}{|c|}{ Parasitism Rate (IP) and Parasitism Reduction (RP) } \\
\hline & & IP revious $(\%)$ & IP 15DAA (\%) & $\mathrm{RP} *(\%)$ & IP 30DAA (\%) & $\mathrm{RP}(\%)$ & IP 45DAA (\%) & $\mathrm{RP}(\%)$ \\
\hline \multirow{5}{*}{ Cyantraniliprole } & 28.1 & 5.7 & 8.0 & $-23.08 \mathrm{~N} * *$ & 0.0 & $100.0 \mathrm{~T}$ & 3.0 & $78.57 \mathrm{~T}$ \\
\hline & 60.5 & 2.6 & 12.0 & $-84.61 \mathrm{~N}$ & 11.1 & $-38.75 \mathrm{~N}$ & 10.5 & $25.00 \mathrm{~N}$ \\
\hline & 80.2 & 6.1 & 8.9 & $-36.92 \mathrm{~N}$ & 5.9 & $26.25 \mathrm{~N}$ & 2.8 & $80.00 \mathrm{~T}$ \\
\hline & 180.0 & 4.7 & 12.5 & $-92.30 \mathrm{~N}$ & 6.3 & $21.25 \mathrm{~N}$ & 4.6 & $67.14 \mathrm{M}$ \\
\hline & 28.1 & 4.4 & 5.3 & $18.46 \mathrm{~N}$ & 5.3 & $33.75 \mathrm{~N}$ & 0.0 & $100.00 \mathrm{~T}$ \\
\hline \multirow{3}{*}{$\begin{array}{c}\text { Cartape } \\
\text { hydrochloride }\end{array}$} & 60.5 & 3.0 & 13.3 & $-104.61 \mathrm{~N}$ & 14.3 & $-78.75 \mathrm{~N}$ & 5.7 & $59.28 \mathrm{M}$ \\
\hline & 80.2 & 5.9 & 8.3 & $-27.69 \mathrm{~N}$ & 6.5 & $18.75 \mathrm{~N}$ & 3.0 & $78.57 \mathrm{~T}$ \\
\hline & 180.0 & 2.0 & 9.4 & $-44.61 \mathrm{~N}$ & 8.7 & $-8.75 \mathrm{~N}$ & 9.3 & $33.57 \mathrm{~N}$ \\
\hline \multirow{5}{*}{$\begin{array}{c}\text { Beta- } \\
\text { cypermethrin }\end{array}$} & 28.1 & 6.7 & 5.2 & $20.00 \mathrm{~N}$ & 3.0 & $62.50 \mathrm{~N}$ & 3.6 & $74.28 \mathrm{M}$ \\
\hline & 60.5 & 3.6 & 9.7 & $-49.23 \mathrm{~N}$ & 12.7 & $-58.80 \mathrm{~N}$ & 12.2 & $12.86 \mathrm{~N}$ \\
\hline & 80.2 & 4.1 & 7.7 & $-18.46 \mathrm{~N}$ & 0.0 & $100.00 \mathrm{~T}$ & 6.0 & $57.14 \mathrm{M}$ \\
\hline & 180.0 & 0.0 & 10.2 & $-56.92 \mathrm{~N}$ & 15.9 & $-98.75 \mathrm{~N}$ & 5.7 & $59.28 \mathrm{M}$ \\
\hline & Control & 0.0 & 6.5 & & 8.0 & & 14.0 & \\
\hline
\end{tabular}

* Parasitism reduction determined by the Abbott's formula (1925).

** Classification of selectivity according to Boller et al. (2005), where: N: harmless or slightly toxic; M: moderately toxic; T: toxic. 
With regard to cartape hydrochloride, often used as a standard insecticide for the control of leaf miner, Melo et al. (2019) observed reduction in parasitism using higher insecticide application rates (146 and $309 \mathrm{~L} \mathrm{ha}^{-1}$ ) with the addition of adjuvant until 15 DAA in coffee cultivation in the western region of Bahia, which is considered toxic to pest parasites. However, these results are in disagreement with those observed in the study, as cartape hydrochloride is toxic at 15 DAA at lower application rates (28.1 and $80.2 \mathrm{~L} \mathrm{ha}^{-1}$ ). The toxic effects of cartape hydrochloride on leaf miner predators range from toxic to moderately toxic. Cartape hydrochloride can reduce parasitism (Carvalho; Parra; Baptista, 1999) and affect the sex ratio (Carvalho; Parra; Baptista, 2003) of Trichogramma pretiosum Riley in tomato crops. In cotton, this insecticide is classified as toxic to the main natural enemies of the crop (Crosariol Netto; Degrande; Melo, 2014).

In general, pyrethroids have high toxicity to insects, presenting low selectivity in favor of natural enemies. Betacypermethrin insecticide is classified as toxic to the main natural enemies of cotton (Crosariol Netto; Degrande; Melo, 2014). Another chemical group used to control L. coffeella is that of organophosphates, which show high toxicity to wasp species that predate leaf miner insects, such as the chlorpyrifos insecticide (Fragoso et al., 2001).

Pearson correlations did not indicate significant interactions between infestation and parasitism for insecticides and application rates (Table 9), making it difficult to analyze the impact of insecticides on parasitism. In the available literature, there is scarcity of studies on the probable impacts of insecticides on the leaf miner parasitism.

Table 9: Pearson correlation among biological variables, Leucoptera coffeella infestation and parasitism as a function of application rates in coffee crops and insecticides. Barra do Choça, BA, 2017.

\begin{tabular}{|c|c|c|c|c|}
\hline & \multicolumn{4}{|c|}{ Parasitism - Insecticide } \\
\hline & $\begin{array}{l}\text { Volume } \\
\left(\mathrm{L} \mathrm{ha}^{-1}\right)\end{array}$ & Cyantraniliprole & $\begin{array}{c}\text { Cartape } \\
\text { Hydrochloride }\end{array}$ & $\begin{array}{c}\text { Beta- } \\
\text { Cypermethrin }\end{array}$ \\
\hline \multirow{4}{*}{ 离 } & 28.1 & $-0.6489^{\mathrm{ns}}$ & $-0.1107^{\mathrm{ns}}$ & $-0.3723^{\mathrm{ns}}$ \\
\hline & 60.5 & $0.0133^{\mathrm{ns}}$ & $-0.5238^{\mathrm{ns}}$ & $0.2420^{\mathrm{ns}}$ \\
\hline & 80.2 & $0.0549^{\text {ns }}$ & $-0.8020^{\mathrm{ns}}$ & $-0.0564^{\mathrm{ns}}$ \\
\hline & 180.0 & $0.7483^{\mathrm{ns}}$ & $0.0674^{\mathrm{ns}}$ & $0.4152^{\mathrm{ns}}$ \\
\hline
\end{tabular}

\section{CONCLUSIONS}

The application rate of insecticide sprays on coffee plants interferes with qualitative aspects (number and density of droplets, volumetric and numeric median diameter, coverage and recovery volume) and on the spray deposition levels;
Considering the quality-quantitative aspects and agronomic efficacy, application rates between 80.2 and 180.0 $\mathrm{L} \mathrm{ha}^{-1}$ are more adequate in the leaf miner control of 8-year-old 'Catucaí' cultivar;

Cyantraniliprole insecticide is effective in controlling L. coffeella up to $45 \mathrm{DAA}$ at application rate of $180.0 \mathrm{~L} \mathrm{ha}^{-1}$;

The impact of cyantraniliprole, cartape hydrochloride and beta-cypermethrin insecticides on $L$. coffeella natural parasitism varies with application rates and time after application.

\section{ACKNOWLEDGEMENTS}

Weare grateful to the Foundation for Research Support of the State of Bahia (FAPESB), and the CAPES Foundation (Brazilian Ministry of Education; Finance Code 001) for financial support.

\section{REFERENCES}

ABBOTT, W. S. A method of computing the effectiveness of an inseticide. Journal of Economic Entomology, 18(1):265-267, 1925.

ALVES, G. S.; CUNHA J. P. A. R.; PALlADINI, L. A. Seleção de traçadores para estudos de eficiência das aplicações de produtos fitossanitários. Planta Daninha, 32(4):861-870, 2014.

AMERICAN SOCIETY OF AGRICULTURAL AND BIOLOGICAL ENGINEERING. ASABE S572. Spray nozzle classification by droplet spectra. St. Joseph, 2009. 8p.

BOLLER, E. F. et al. Working document on selectivity of pesticides. International Organization for Biological and Integrated Control of Noxious Animals and Plants. 2005. Available in: $<$ https:// www.iobc-wprs.org/ip_ipm/archive/03021_IOBC WorkingDocumentPesticides_Explanations.pdf $>$. Access in: April 14, 2019.

CARVAlHO, G. A.; PARRA, J. R. P.; BAPTISTA, G. C. de. Ação residual de alguns inseticidas pulverizados em plantas de tomateiro sobre duas linhagens de Trichogramma pretiosum Riley, 1879 (Hymenoptera: Trichogrammatidae) em casa-de-vegetação. Ciência e Agrotecnologia, 23(4):771-776, 1999.

CARVAlHO, G. A.; PARRA, J. R. P.; BAPTISTA, G. C. Bioatividade de produtos fitossanitários utilizados na cultura do tomateiro (Lycopersicon esculentum Mill.) a Trichogramma pretiosum Riley, 1879 (Hymenoptera: Trichogrammatidae) nas gerações F1 E F2. Ciência e Agrotecnologia, 27(2):261-270, 2003. 
CASTELLANI, M. A.; MELO, T. L.; MENEZES, M. A. P. Desafios para o Manejo do Bicho-mineiro. Aiba Rural, Barreiras, n 5, ano II, p. 40-41, 2016.

CHRISTOFOLETTI, J. C. Considerações sobre a deriva nas pulverizações agrícolas e seu controle. São Paulo: TeeJet South America, 15p. 1999.

CROSARIOL NETTO, J.; DEGRANDE, P. E.; MELO, E. P. Seletividade de inseticidas e acaricidas aos inimigos naturais na cultura do algodão. Circular Técnica, 81(14):150-158, 2014.

CUNHA, J. P. A. R. da. et al. Avaliação de estratégias para redução da deriva de agrotóxicos em pulverizações hidráulicas. Planta Daninha, 21(2):325-332, 2003.

DECARO JUNIOR, S. T. et al. Reducing spray volume for the control of Leucoptera coffeella (Lepidoptera: Lyonetiidae) in coffee plants. Coffee Science, 10(4):491498, 2015.

\section{EMPRESA BRASILEIRA DE PESQUISA} AGROPECUÁRIA- EMBRAPA. Relatório de Atividades da Embrapa Café de 2014. Available in: http://www.sapc.embrapa.br/arquivos/ consorcio/publicacoes_tecnicas/Relatorio_de atividades_2014_-_2-3-2015.pdf. Access in: January, 14, 2017.

FERREIRA, M. C. da et al. Qualidade da aplicação de inseticida em amendoim (Arachis hypogaea L.), com e sem adjuvantes na calda, sob chuva simulada. Bioscience Journal, 29(Sup.1):1431-1440, 2013.

FRAGOSO, D. B. et al. Seletividade de Inseticidas a vespas predadoras de Leucoptera coffeella (Guér.-Mènev.) (Lepidoptera: Lyonetiidae). Neotropical Entomology, 30(1):139-144, 2001.

GITIRANA-NETO, J. et al. Deposição de calda promovida por pulverizadores empregados na cafeicultura de montanha. Coffee Science, 11(2):267-275, 2016.

HENDERSON, C. F.; TILTON, E. W. Tests with acaricides against the brown wheat mite. Journal of Economic Entomology, 48(2):157-161, 1955.

MAGNOJET. Bicos e acessórios para pulverização. Produtos Agrícolas, v. 9, 112p. 2015.

MINISTÉRIO DA AGRICULTURA, PECUÁRIA E ABASTECIMENTO - MAPA, AGROFIT: Sistema de Agrotóxicos Fitossanitários. MAPA/CGAF/DFIA/DAS, Brasilia, DF, Brazil, 2017. Available in: http://agrofit. agricultura.gov.br/agrofit_cons/principal_agrofit_cons. Access in: April, 22, 2017.
MELO, T. L. et al. Comunidades de Parasitóides de Leucoptera coffeella (Guérin-Meneville \& Perrotet, 1842) (Lepidoptera: Lyonetiidae) em cafeeiros nas regiões Oeste e Sudoeste da Bahia. Ciência e Agrotecnologia, 31(4):966-972, 2007.

MELO, T. L. et al. Management of coffee leaf miner: Spray volume, efficacy ofcar tap hydrochloride and impact on parasitismo. Coffee Science, 14(2):250260, 2019.

MIRANDA, G. R. B. et al. Avaliação dos depósitos da pulverização em frutod de cafeeiro utilizando dois equipamentos associados a diferentes volumes de calda. Revista Agroambiental, 4(1):15-20, 2012.

MIRANDA, G. R. B. et al. Equipamentos de pulverização associados a volume de calda e avaliados por alvos artificiais em cafeeiro. Revista Agrarian, 6(22):448-459, 2013.

MORAIS, J. L. C. et al. Lambda-cyhalothrin efficiency on fruit borer control and quali-quantitative spraying aspects in a pinecone crop. Ciência e Agrotecnologia, 40(3):288$297,2016$.

OZEKI, Y.; KUNZ, R. P. Tecnologia de aplicação aérea Aspectos práticos. In: GUEDES, J. V. C.; DORNELLES, S. H. B. Tecnologia e segurança na aplicação de agrotóxicos. Santa Maria: Defesa Fitossanitária; Sociedade de Agronomia de Santa Maria, p. 65-78. 1998.

PARRA, J. R. P.; REIS, P. R. Manejo integrado para as principais pragas da cafeicultura no Brasil. Visão Agrícola, 8(12):47-50, 2013.

REIS, P. R.; SOUZA, J. C. Insetos na folha. Cultivar, 4(39):30-33, 2002.

RIBEIRO JUNIOR, J. I. Análises Estatísticas no SAEG. Viçosa, Universidade Federal de Viçosa: UFV, 301p. 2001.

ROCHA, L. C. D. et al. Seletividade fisiológica de inseticidas utilizados em cultura cafeeira sobre ovos e adultos de Cryptolamus montrouzieri Mulsant. Arquivos do Instituto Biológico, 77(1):119-127, 2010.

ROCHA, L. C. D. et al. Seletividade fisiológica de inseticidas utilizados em cultura cafeeira para larvas de Cryptolamus montrouzieri Mulsant. Ciência Rural, 41(6):939-946, 2011.

RODRIGUES, G. J. et al. Otimização da pulverização de inseticidas visando o controle do bicho-mineiro do cafeeiro. Revista Agrotecnologia, 3(1):70-80, 2012. 
SANTINATO, F. et al. Deposição da calda de pulverização em diferentes volumes vegetativos de Coffea arabica L. Coffee Science, 12(1):69-73, 2017.

SCUDELER, F. et al. Cobertura da pulverização e maturação de frutos do cafeeiro com ethephon em diferentes condições operacionais. Bragantia, 63(1):129-139, 2004.

SILVA, J. E. R.; CUNHA, J. P. A. R. da; NOMELINI, Q. S. S. Deposição de calda em folhas de cafeeiro e perdas para o solo com diferentes taxas de aplicação e pontas de pulverização. Revista Brasileira de Engenharia Agrícola e Ambiental, 18(12):13021306, 2014.
SOUZA, R. T. de; PALLADINI, L. A. Tecnologia para aplicação de produtos fitossanitários em videira. Circular Técnica, 73, Embrapa: Bento Gonçalves, RS. 8p, 2007.

SOUZA, T. P. et al. Ocorrência sazonal, predação e parasitismo de Leucoptera coffeella (Guérin-Méneville, 1842) (Lepidoptera: Lyonetiidae) em cafeeiros associados a grevíleas. Coffee Science, 9(1):34-50, 2014.

WOLF, R. E. Strategies to reduce spray drift. Kansas: Kansas State University, 2000. 4p. (Application Technology Series).

ZHU, H. et al. Simulation of drift of discrete sizes of water droplets from field sprayers. Transactions of the ASAE, 37(5):1401-1407, 1994. 